\title{
UPAYA PENINGKATAN PENGETAHUAN HIDUP SEHAT MENCEGAH COVID-19 BAGI MASYARAKAT DI DESA MARGA SAKTI KECAMATAN PADANG JAYA KABUPATEN BENGKULU UTARA
}

\author{
Diyas Widiyarti M.A \\ Sosiologi/FISIP \\ UNIB/diyas.widiyarti@unib.ac.id \\ Drs. Heri Sunaryanto, M.A., Ph.D \\ Sosiologi/FISIP \\ UNIB/hsuharyanto50@gmail.com \\ Drs. Sumarto Widiono, M.Si \\ Sosiologi/FISIP \\ UNIB/sumarto.widiono@unib.ac.id
}

\begin{abstract}
ABSTRAK
Pengabdian kepada masyarakat bertujuan agar meningkatkan pengetahuan bagi masyarakat desa Marga Sakti Kecamatan Padang Jaya Kabupaten Bengkulu Utara perihal budaya hidup sehat, dengan adanya dampak dari corona virus 19 yang telah mewabah kepenjuru dunia. Metode pengabdian dilakukan dengan cara ceramah dengan pendampingan bersama narasumber yang berkopetensi yaitu dokter umum yang bertugas sebagai anggota satgas covid dilingkungan rumah sakit rafflesia Bengkulu dan tim dari pengabdian kepada masyarakat melalui penguatan prilaku sosial dalam berinteraksi sehari-hari. Hasil pengabdian diketahui bahwa kesadaran yang tidak berkelanjutan atau konsisten dari masyarakat sehingga budaya menggunakan protokol kesehatan masih dijalankan tidak sesui kebijakan pemerintah yang telah disosialisasikan sehingga peran komunikasi dan interaksi yang intensif dilakukan dengan selalu melakukan sosialisasi dalam saling mengingatkan tatkala tidak menggunakan masker, mencuci tangan dengan air sabun serta menjaga jarak yang wajib dilakukan, diakhir kegiatan tim PPM memberikan keterampilan membuat masker instan.
\end{abstract}

Kata Kunci : Peningkatan Pengatahuan, Hidup Sehat, Masyarakat Desa Marga Sakti.

\section{PENDAHULUAN}

Kesehatan merupakan aspek terpenting dalam kehidupan dan mendukung berjalannya aktivitas secara optimal. Kesehatan diartikan sebagai kondisi fisik,mental dan sosial yang terbebas dari gangguan penyakit sehingga aktivitas yang berjalan di dalamnya dapat terjadi secara optimal. Untuk mencapai standar kesehatan yang baik maka diperlukan adanya proses pengelolaan lingkungan sekitar dan aktivitas harian yang tercermin dalam gaya hidup sehat. Gaya hidup sehat merupakan gaya hidup masyarakat yang menjunjung tinggi aspek-aspek kesehatan seperti pengelolaan kebersihan dan kesehatan lingkungan, menjaga kebugaran fisik 
dan psikis dan pemberian asupan nutrisi yang cukup, sehingga tercapai standar kesehatan yang baik.

Pada tahun 2020 berkembang kasus wabah virus covid-19 (corona virus) yang sangat menjadi perhatian dunia muncul pertama kali di negara cina (di kota wuhan) pada desember 2019 dan sampai berkembang salah satunya yaitu di negara indonesia. Wabah virus covid-19 merupakan salah satu virus yang mematikan sehingga kasus ini menjadi pusat perhatian oleh setiap individu, 34 provinsi di indonesia telah terpapar zona merah atau warga yang bermukim di suatu provinsi tersebut telah menjadi korban baik yang telah memeriksakan diri (PPT), orang dalam pemantauan (ODP), pasien dalam pengawasan (PDP), orang tanpa gejala (OTG), pasien dalam perjalanan dalam negeri/area terjangkit (PPT) dan terkonfirmasi atau (POSITIF COVID 19).

Bengkulu menjadi salah satu wilayah tersasar suspect korban covid 19 yang tercatat pada tanggal 09 april 2020 data yang direalist oleh dinas kesehatan kota bengkulu:

Tabel 01.

Dinas Kesehatan Dalam Rilist Pasien Covid-19

\begin{tabular}{|c|c|c|c|}
\hline No & Pasien Tercatat & Jumlah/Jiwa & Keterangan \\
\hline 1 & $\begin{array}{l}\text { Penjaringan } \\
\text { Pemeriksaan }\end{array}$ & 6338 & - \\
\hline 2 & PPT & 1236 & - \\
\hline 3 & PDP & 8 & $\begin{array}{l}2 \text { jiwa= dirawat, } 1 \text { jiwa =pulang, } 5 \text { jiwa } \\
\text { =meninggal }\end{array}$ \\
\hline 4 & ODP & 127 & $\begin{array}{l}76 \text { jiwa=proses pemantauan, } 50 \text { jiwa } \\
=\text { selesai pemantauan, } 1 \text { jiwa }=\text { meninggal }\end{array}$ \\
\hline 5 & OTG & 76 & \\
\hline 6 & Terkonfirmasi & 4 & \\
\hline
\end{tabular}

Sumber: Dinas Kesehatan Kota Bengkulu, 09 April 2020, Pukul 17.00 WIB Faktor-

faktor yang bisa menyebabkan terinfeksi virus ini, yaitu:

1. Terapkan physical distancing, yaitu menjaga jarak minimal 1 meter dari orang lain, dan jangan dulu ke luar rumah kecuali ada keperluan mendesak.

2. Gunakan masker saat beraktivitas di tempat umum atau keramaian.

3. Rutin mencuci tangan dengan air dan sabun atau hand sanitizer yang mengandung alkohol minimal $60 \%$ setelah beraktivitas di luar rumah atau di tempat umum.

4. Tingkatkan daya tahan tubuh dengan pola hidup sehat.

5. Jangan menyentuh mata, mulut, dan hidung sebelum mencuci tangan.

6. Hindari kontak dengan penderita atau orang yang dicurigai menderita COVID-19.

7. Tutup mulut dan hidung dengan tisu saat batuk atau bersin, kemudian buang tisu ke tempat sampah. 
8. Hindari berdekatan dengan orang yang sedang sakit demam, batuk, atau pilek.

9. Jaga kebersihan benda yang sering disentuh dan kebersihan lingkungan, termasuk kebersihan rumah (artikel.kementerian kesehatan 2020).

Dari adanya hasil observasi kasus covid 19 yang telah terpaparkan datanya diatas menjelaskan bahwa gaya hidup merupakan salah satu aspek yang esensial di era modern ini. Gaya hidup merupakan gambaran bagi setiap orang yang mengenakannya dan menggambarkan seberapa besar prilaku seseorang di dalam masyarakat. Selain itu, gaya hidup juga dapat diartikan sebagai suatu seni yang dibudayakan oleh setiap orang. Gaya hidup yang dijalani dapat menentukan kualitas hidup dan kesehatan tubuh. Seseorang yang memiliki gaya hidup yang positif dan pola hidup yang sehat cenderung memiliki kualitas hidup yang lebih memadai, begitu juga sebaliknya. Gaya hidup merupakan salah satu indikator kualitas hidup seseorang. Seseorang yang memiliki gaya hidup sehat akan menjalankan kehidupannya dengan memperhatikan faktor-faktor yang mempengaruhi kesehatan seperti makanan, pikiran, kebiasaan olahraga, dan lingkungan yang sehat.

Menurut data WHO 2019, 70 \% kematian disebabkan oleh berbagai penyakit : jantung, diabetes, stroke, dan kanker. Separuh orang dari jumlah tersebut memiliki pola makan yang buruk. Pola makan modern pemicu utama timbulnya penyakit degeneratif. pola makan modern tidak sesuai dengan pengertian pola hidup sehat, terlalu banyak karbohidrat dan lemak serta kekurangan mengonsumsi serat serta sering memakan makanan yang cepat saji yang mengandung pengawet, kalori kosong, penyedap rasa, dan lemak. Selain itu kebiasaan ngemil yang berlebihan, merokok juga dapat memiliki dampak buruk bagi kesehatan karena di dalam rokok mengandung zat kimia berbahaya bagi kesehatan tubuh, temuan pada kasus terbaru ini tahun 2020 ialah wabah virus covid 19 (corona) yang mengakibatkan kematian pada diri manusia. Wabah virus corona ini sampai saat ini belum ditemukan jenis pengobatan yang tepat namun perlu dan pentingnya melalui pencegahan sebagai berikut kegiatan yang sederhana menggunakan masker dan melalukan kegiatan cuci tangan (pakai sabun) sangat penting mengingat tangan adalah salah satu media yang sangat potensial sebagai perantara masuknya berbagai penyakit didalam tubuh (dalam Sumarto 2019).

Nilai positif secara sosial pada akhirnya beberapa kelompok masyarakat/individu mulai menumbuhkan kesadaran untuk menyadari pentingnya menjaga kesehatan. Berbagai cara 
dilakukan agar mendapat kesehatan yang optimal. Menurut World Health Organization, health is a state of complete physical, mental and social well-being and not merely the absence of diseases or infirmity . Dengan demikian standarisasi kebiasaan atau prilaku hidup setiap individu sangatlah berbeda, maka strategi yang dilakukan menunjukkan bagaimana kualitas survive pada setiap individu.

Menjadi pusat perhatian yaitu kepada kelompok usia rentan pada umur antara 55-65 tahun keatas memiliki pengaruh resiko yang tinggi perihal menjaga kesehatan sehingga perlunya inisiasi atau pendampingan yang kompleks dalam melukan komunikasi dan sosialisasi menjadi upaya sebagai salah satu tindakan preventif yang mendukung tercapainya kesadaran dan perubahan gaya hidup menjadi lebih baik.

Desa marga sakti menjadi salah satu lokus kajian pengabdian ini, dimana bila dilihat berdasarkan fasilitas kesehatan yang ada yaitu: 
TABEL 02.

SARANA DAN

PRASARANA DESA

MARGA SAKTI

\begin{tabular}{|c|c|c|}
\hline NO & SARANA/PRASARANA & $\begin{array}{c}\text { JUMLAH/VOLU } \\
\text { ME }\end{array}$ \\
\hline 1 & Balai Desa & 1 Unit \\
\hline 2 & Kantor Desa & 1 Unit \\
\hline 3 & Puskesmas Pembantu & 1 Unit \\
\hline 4 & Masjid & 14 Unit \\
\hline 5 & Mushola & 32 Unit \\
\hline 6 & Gereja & 5 Unit \\
\hline 7 & Pos Kamling & 44 Unit \\
\hline 8 & Taman Kanak-kanak & 5 Unit \\
\hline 9 & Lapangan Bola kaki & 1 unit \\
\hline 10 & SD Negeri & 4 Unit \\
\hline 11 & SMP Negeri & 1 Unit \\
\hline 12 & Balai Desa & 1 Unit \\
\hline 13 & Balai Pertemuan Serba Guna & 1 Unit \\
\hline 14 & Gedung Posyandu & 2 unit \\
\hline 15 & Terminal Desa & 1 Unit \\
\hline 16 & Tempat Pemakaman Umum & 5 Lokasi \\
\hline 17 & Pasar Desa & 2 unit \\
\hline 18 & Sungai & $4300 \mathrm{~m}$ \\
\hline 19 & Jalan Tanah & $9000 \mathrm{~m}$ \\
\hline 20 & Jalan Koral & $18000 \mathrm{~m} ’$ \\
\hline 21 & Jalan Poros/Hot Mix & 8000 m’ \\
\hline 22 & Jalan aspal Penetrasi & $15000 \mathrm{~m}$ \\
\hline 23 & PDAM & 5 unit \\
\hline 24 & BANK Perkreditan & 1 unit \\
\hline 25 & Koperasi & 3 unit \\
\hline
\end{tabular}

Darmabakti: Jurnal Inovasi Pengabdian dalam Penerbangan 
Politeknik Penerbangan Palembang

\begin{tabular}{|l|l|c|}
\hline 26 & Pembibitan Karet & 5 kelompok \\
\hline 27 & Balai Benih Ikan & 2 unit \\
\hline
\end{tabular}

Sumber : Profil Desa Marga Sakti, 2020. 
Dari beberapa sarana fisik yang tersedia, hasil observasi (tim pengabdian februari 2020) belum ditindak lanjutinya penyediaan fasilitas peningkatan tanggap situasi covid-19 terjadi saat ini, sehingga desa marga sakti yang memiliki jumlah kepala keluarga 1970 kk dan tujuh dusun dengan jumlah penduduk 6.240 jiwa yang terdiri dari :

Tabel 03.

Jumlah Penduduk Desa Marga Sakti/ Maret 2020

\begin{tabular}{|c|c|}
\hline Jenis Kelamin & $\begin{array}{c}\text { Gambaran Jumlah Penduduk } \\
\text { Dalam Jiwa }\end{array}$ \\
\hline Laki-Laki & 3.203 Jiwa \\
\hline Perempuan & 3.037 Jiwa \\
\hline
\end{tabular}

Sumber : Profil Desa Marga Sakti, 2020.

Inisiatif yang akan dilakukan oleh tim pengabdian ialah pendampingan dan sosialisasi yang dimaksudkan sebagai upaya bagi masyarakat menumbuhkan pengetahuan mengenai perubahan sosial yang terjadi. Kesadaran menjalankan prilaku hidup sehat, dengan beradaptasi pada kasus yang sedang terjadi saat ini, memberikan pengetahuan mengenai strategi dan langkah yang dilakukan oleh masyarakat desa marga sakti menghadapi dan mencegah pandemi virus covid-19, implementasi bersinergi pada program kementerian kesehatan yaitu penerapan gerakan masyarakat hidup sehat dalam keluarga serta adanya penyediaan masker dan fasilitas pencuci tangan yang akan disediakan oleh tim pengabdian sebagai role model tertib protokol kesehatan pemerintah.

\section{METODE}

Sasaran dari kegiatan ini ialah kelompok masyarakat desa marga sakti kecamatan padang jaya kabupaten bengkulu utara, diawali dengan melakukan koordinasi oleh tim pengabdian kepada perangkat desa marga sakti hingga disepakati jumlah peserta sebanyak 40 orang yang terbagi dalam dua hari kegiatan sesuai dengan instruksi protokol kesehatan pemerintah dalam satu hari ialah 20 orang. Adapun upaya pemecahan masalah melalui beberapa metode yaitu:

a Diskusi merupakan salah upaya dialogis secara tearah yang memuat kegiatan tanya jawab mengenai persoalan yang terkait dengan topik yang disajikan serta mengulas mengenai upaya peningkatan pengetahuan hidup sehat mencegah covid-19 bagi masyarakat desa marga sakti kecamatan padang jaya kabupaten bengkulu utara. Dalam kegiatan ini, para peserta diberikan kesempatan seluas-luasnya untuk bertanya 
guna mendapatkan informasi dan pengetahuan secara mendalam.

b. Pendampingan merupakan kegiatan yang dilakukan pasca pemberian informasi mengenai upaya peningkatan pengetahuan hidup sehat mencegah covid-19. Pada kesempatan ini, tim pengabdian masyarakat akan memberikan skill dalam membuat masker secara sederhana. Upaya ini merupakan salah satu strategi dalam menghadapi pencegahan covid-19 di desa marga sakti.

\section{HASIL DAN PEMBAHASAN}

\section{Menjalin Komunikasi Dan Koordinasi Dengan Agent}

Kegiatan pengabdian masyarakat ini dimulai dengan langkah koordinasi antar anggota tim PPM sebagai upaya persiapan kegiatan dengan mengunjungi kepala desa marga sakti pada hari selasa, 15 september 2020 tepat pada pukul 09.30 tiba di balai desa marga sakti berbicara dengan mengutarakan maksud kedatangan tim PPM maka kepala desa menyambut dengan baik rencana dan selanjutnya meminta tim PPM untuk langsung berkoordinasi dengan sekretaris desa marga sakti yaitu bapak endro pradopo. Bapak endro adalah sekretaris desa yang sudah bekerja selama 5 tahun mengabdi didesa marga sakti, dedikasi yang telah dilakukannya telah banyak mengorganisir kegiatan desa marga sakti dan tak kalah penting hasilnya positif dan salah satu prestasi membanggakan desa marga sakti sebagai desa percontohan bagi literasi perpustakaan pada tahun 2017 penghargaan tingkat nasional. Bercerita banyak tentang kegiatan apa saja yang telah dilakukan oleh desa marga sakti selama ini, mendengar maksud dan kedatangan kami, bapak endro yang akrab kami menyapanya serentak langsung merespon sangat positif dikarenakan kegaiatan sosialisasi yang bersamaan dengan kondisi pandemi masih sangat kurang dilakukan, bila ada itu pun kegiatan yang tidak fokus dan spesifik membahas dinamika covid-19 ini. Harapan nya kegiatan kami ini bisa bermanfaat bagi pengembangan pengetahuan informasi dalam berprilaku menghadapi pandemi corona virus-19.

Setelah direspon dengan positif maka kami mendiskusikan mengenai kapan kegiatan ini bisa terselenggarakan. Bapak endro meminta waktu guna menghubungi dan berkoordinasi dengan perangkat desa lainnnya kapan mereka bisa menyediakan waktu untuk kegiatan tersebut. Agar komunikasi dapat berjalan dengan lancar maka kami meminta nomor kontak bapak endro untuk berkoordinasi lebih lanjut. Selesai dengan bapak endro tim PPM berpamitan. 
Lima hari kemudian, bapak endro memberikan kabar mengenai waktu luang mereka untuk mengikuti kegiatan sosialisasi yang telah disiapkan oleh tim PPM. Hasil kesepakatan akhirnya memutuskan bahwa kegiatan sosialisasi akan dilaksanakan dalam 2 kali tahap pertemuan yaitu pada hari Rabu, 23 september 2020 dan Kamis, 24 september 2020 dengan mematuhi protokol kesehatan menentukan jumlah peserta dalam satu hari yaitu 20 orang dengan jumlah keseluruhan 40 peserta yang dibagi dalam dua kali kegiatan pertemuan.

\section{Persiapan Sosialisasi Peningkatan Pengetahuan Hidup Sehat Mencegah Covid 19}

\subsection{Kegiatan Pengabdian Pada Pertemuan Hari Pertama}

Pertemuan hari pertama diselenggarakan pada hari rabu tanggal 23 september 2020 yang dimulai pada pukul 08.30-13.00 WIB. Tim pengabdian masyarakat memulai dengan terlebih dahulu memberikan acara pembukaan secara formal yang didalamnya, dihadiri oleh kepala desa, sekretaris desa, bpd serta perangkat desa dan peserta sosialisasi pada pertemuan satu. Tepat pada pukul 09.00 WIB kegiatan inti dimulai setelah pak kades bernama sumaryono membuka acara secara resmi.

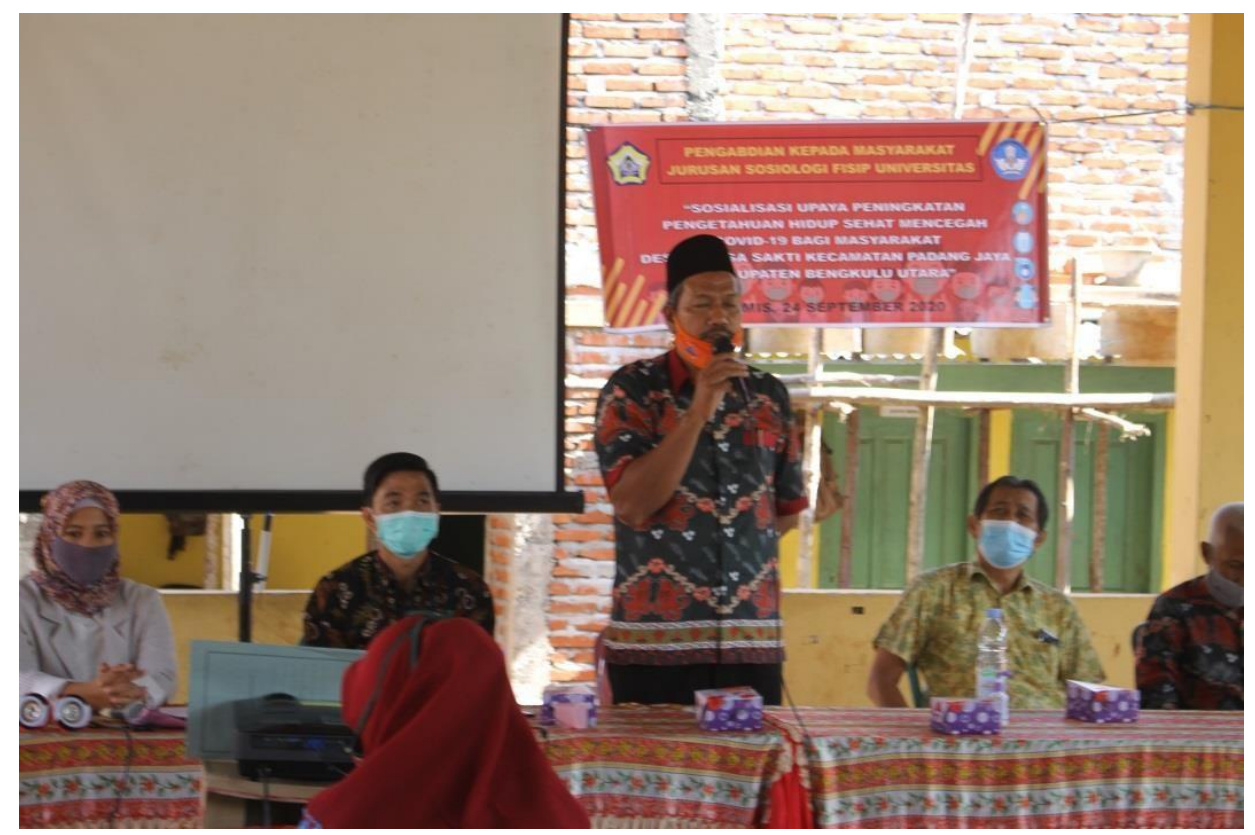

Gambar 01.

Kepala Desa Marga Sakti Bapak Sumaryono Membuka Acara Dengan Resmi. 
Acara pembukaan berjalan dengan lancar, rangkaian acara dilanjutkan dengan tim pengabdian kepada masyarakat memberikan fasilitas pencuci tangan yang telah dibuat kepada kelompok masyarakat desa marga sakti yang telah dipilih sesuai dengan kategori penggunaanya. Adapun jumlah fasilitas pencuci tangan yang telah dibuat sebanyak delapan unit akan ditempatkan di ruang umum seperti : masjid, sekolah (paud), pasar tradisonal, gereja dan kantor desa. Berikut ini adalah dokumentasi peserta daftar perwakilan yang menerima fasilitas tersebut sebagai berikut: 


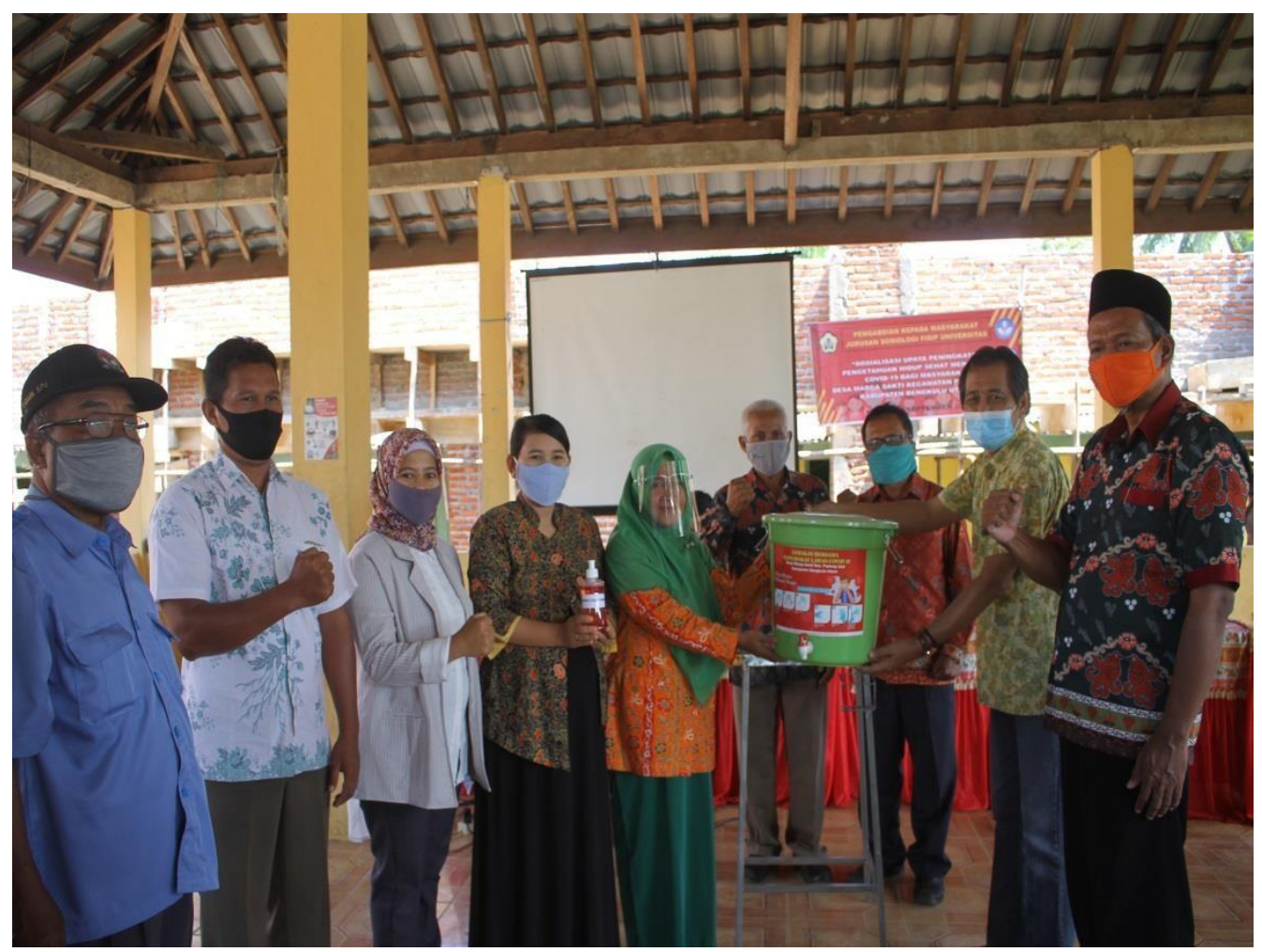

Gambar 02.

Serah Terima Fasilitas Cuci Tangan oleh Tim PPM.

Berikut adalah perwakilan kelompok penerima fasilitas cuci tangan yang diberikan dari tim pengabdian kepada masyarakat di desa marga sakti.

Tabel 04.

\section{Daftar Penerima Fasilitas Pencuci Tangan}

\begin{tabular}{|l|l|l|l|}
\hline No & Nama & Keterangan & Jumlah/Unit \\
\hline 1. & Kasmida & Paud & 1 Unit \\
\hline 2. & Maryastuti & Paud & 1 Unit \\
\hline 3. & Sumaryono & Desa & 1 Unit \\
\hline 4. & Siswanto & Masjid & 1 Unit \\
\hline 5. & Warjuli & Gereja & 1 Unit \\
\hline 6. & M. Jauhari Fajri & Karang Taruna & 1 Unit \\
\hline 7. & Kuzaini & Masjid & 1 Unit \\
\hline 8. & Panut & Masjid & 1 Unit \\
\hline
\end{tabular}

Tepat Pukul 09.15 WIB penyampaian materi dimuali dalam materi sesi 1 disampaikan 
oleh Drs. Sumarto Widiono, M.Si dalam inti materi ini disampaikan tentang "menumbuhkan pengetahuan hidup sehat atas terjadinya perubahan sosial di era modern”. Pada intinya materi ini difokuskan untuk mendeskripsikan perihal situasi perubahan kebudayaan yang terjadi termasuk didalamnya ialah budaya berprilaku yang mendukung pola hidup sehat. Harapannnya mereka dapat memahami dan bisa membedakan bagaimana perubahan sosial yang terjadi pada era modern saat ini.

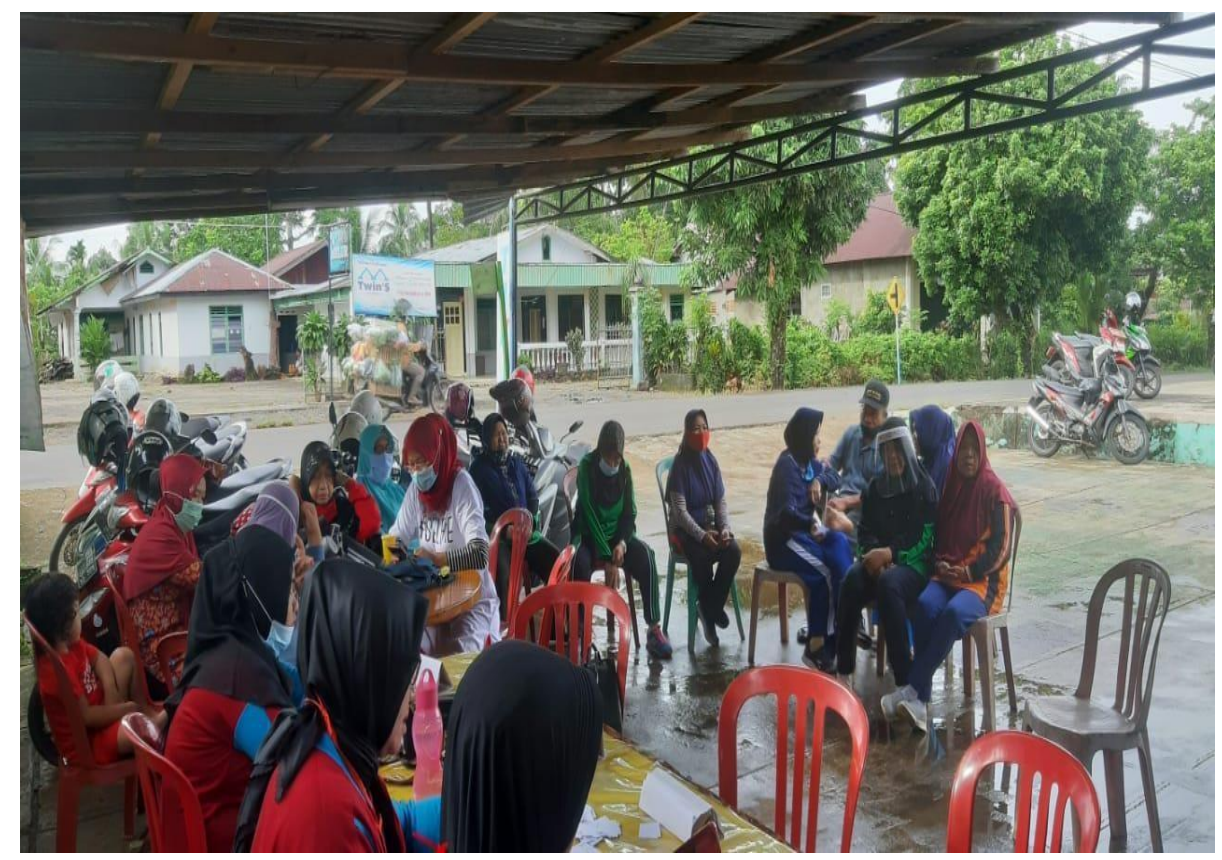

Gambar 03.

Peserta Kelompok 1 Menyimak Materi yang Disampaikan oleh Drs. Sumarto Widiono, M.Si

Kegiatan penyampaian materi pertama selesai dan diskusi berakhir tepat pada pukul 10. 15 WIB. Lalu dilanjutkan dengan pembicara materi kedua oleh Drs. Heri Sunaryanto., Ph.D mengenai "Strategi dan langkah yang dilakukan oleh masyarakat desa marga sakti menghadapi dan mencegah pandemi virus covid-19”. Beliau menjelaskan dengan kata kunci adalah kepatuhan sosial, yang wajib dilakukan oleh seluruh masyarakat tanpa terkecuali dengan budaya baru yang dijalankan dengan harapan kesadaran untuk membiasakan hidup sehat. Materi dan diskusi yang disampaikan oleh pak heri ini berakhir tepat pada pukul 11.15 WIB. 


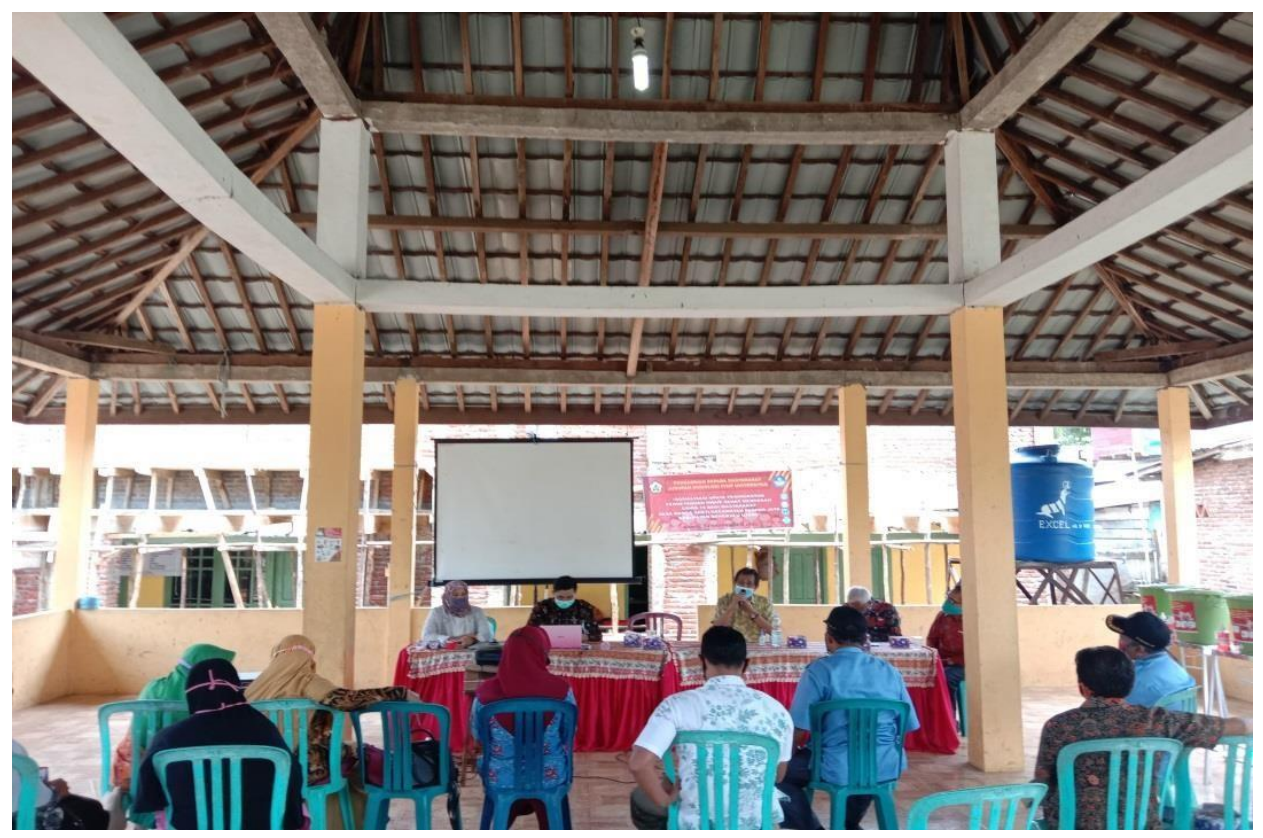

Gambar 04.

Acara penyampaian materi oleh Drs. Heri Sunaryanto, M.A, Ph.D

Terlihat dengan bersemangat antusias peserta dalam berdiskusi perihal materi yang telah disampaikan dalam sesi dua, salah satu peserta bernama bapak tugimin dengan semangatnya mengajukan pertanyaan kepada narasumber.

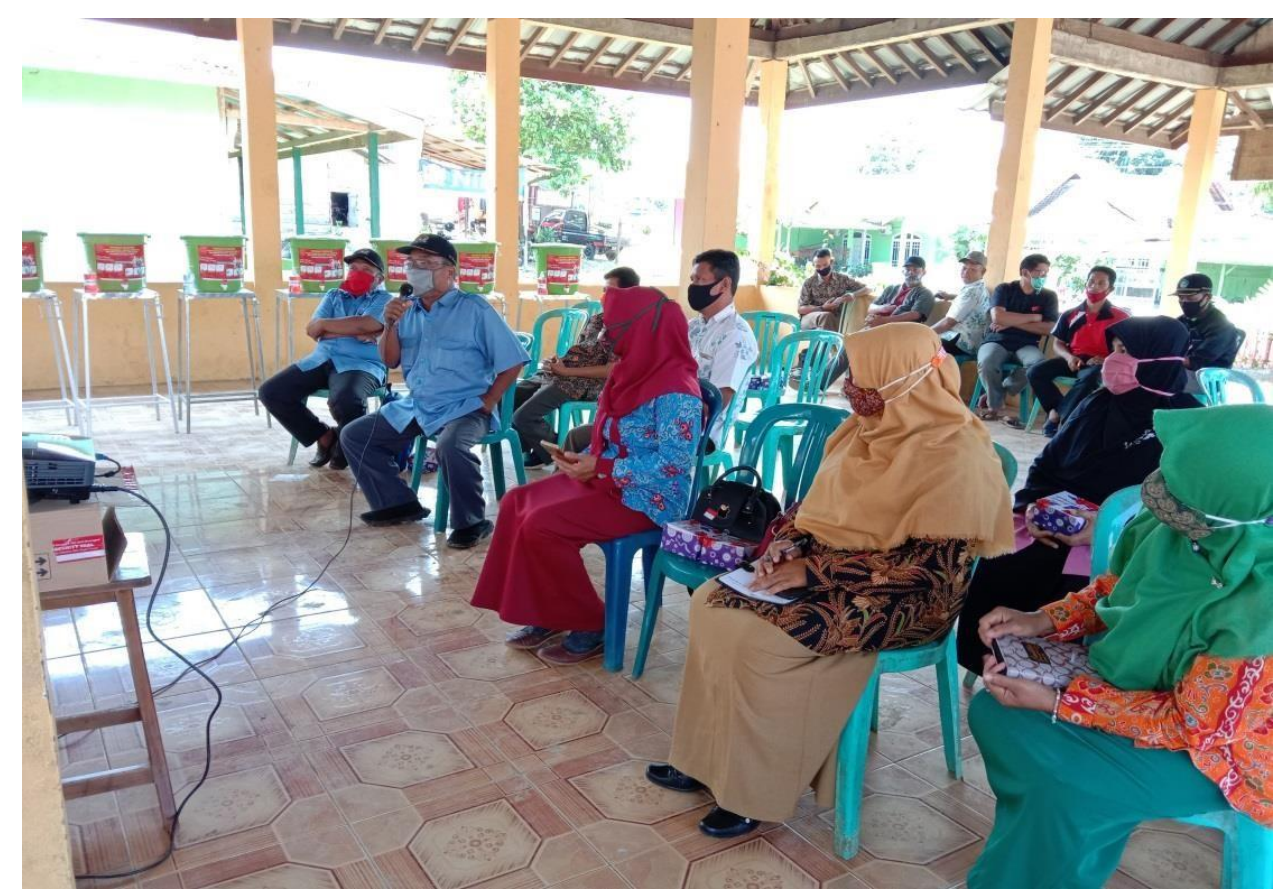

Darmabakti: Jurnal Inovasi Pengabdian dalam Penerbangan

Volume 1, Nomor 1, Desember 2020 
Gambar 05.

Antusias Peserta Dalam Diskusi Kepada Narasumber

Penyampaian materi di sesi ke 3 ialah dari Diyas Widiyarti, M.A yaitu dengan pembahasan terkait praktik pembuatan masker sederhana. Harapannya bahwa masker yang setiap hari dibutuhkan dan digunakan dapat dibuat sendiri dengan pemanfaatan kain yang ada di rumah sehingga tidak menjadi konsumtif membeli masker yang ada di pasar atau toko-toko. Materi sesi 3 berakhir tepat pada pukul 13.00 WIB

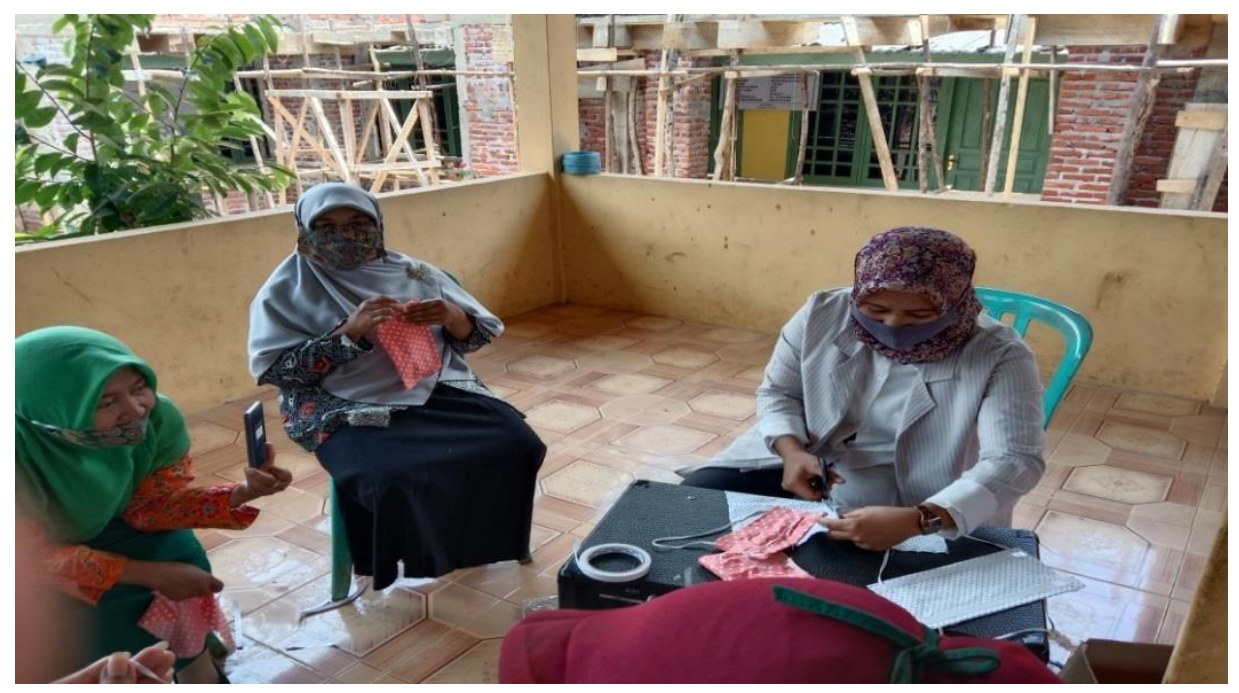

Gambar 06.

Penyampaian Materi oleh Diyas Widiyarti, M.A Membuat Masker Praktis 


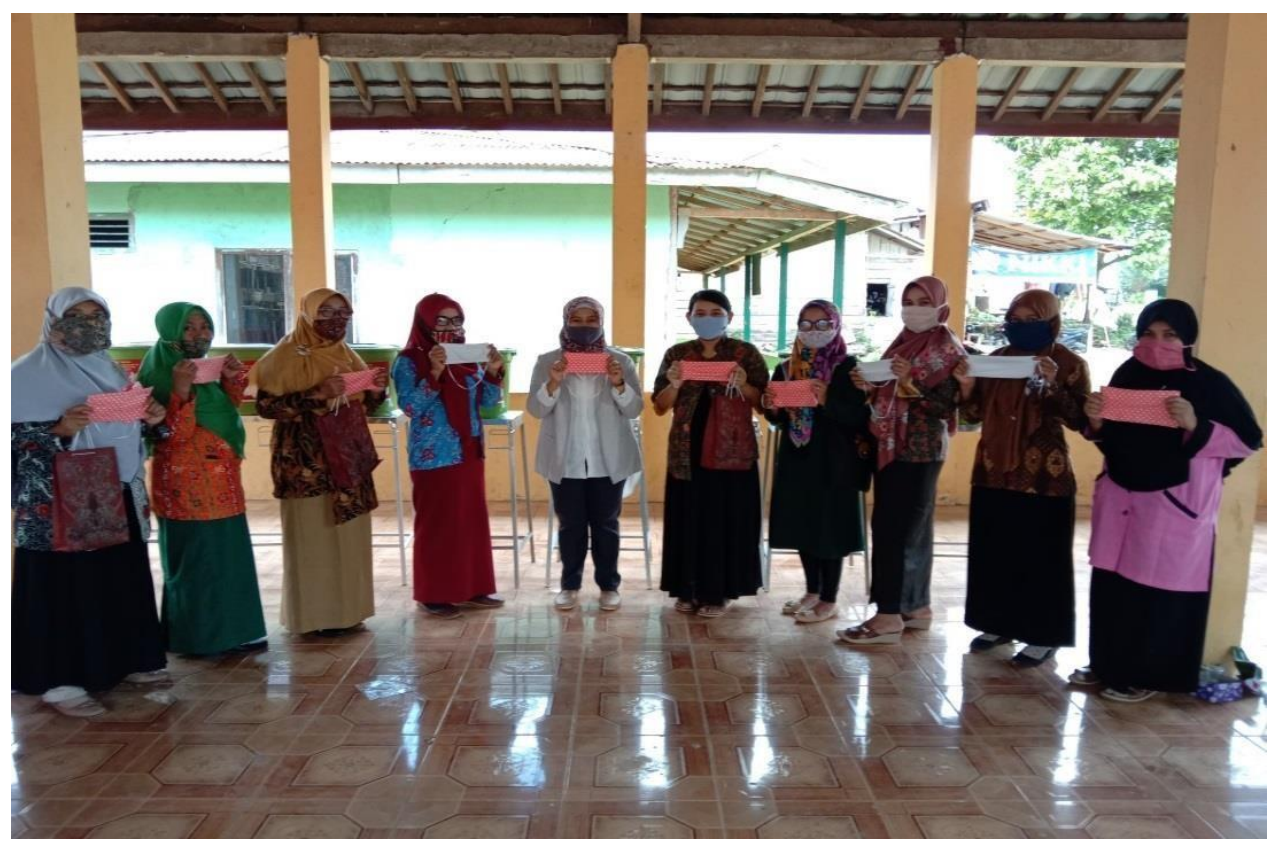

Gambar 07.

Hasil Karya Masker oleh Anggota di Kelompok I

\subsection{Kegiatan Pengabdian Pada Pertemuan Hari Kedua}

Seperti yang telah disepakati bersama, tertib dengan protokol kesehatan (dengan mempertimbangkan jumlah peserta yang telah dibagi menjadi dua kelompok sosialisasi maka pada hari kamis, 24 september 2020 tim PPM berangkat menuju ke lokasi desa marga sakti.

Sesampainya di sana, telah berkumpul kelompok dua yang siap mengikuti serangkaian kegiatan sosialisasi upaya peningkatan pengetahuan budaya hidup sehat sudah menunggu. Kegiatan dimulai tepat pada pukul 09.00 WIB. Pada kesempatan sesi 1, ini penyampaian langsung dari Drs. Heri Sunaryanto, Ph.D D mengenai "Strategi dan langkah yang dilakukan oleh masyarakat desa marga sakti menghadapi dan mencegah pandemi virus covid-19”. Beliau menjelaskan dengan kata kunci adalah kepatuhan sosial, yang wajib dilakukan oleh seluruh masyarakat tanpa terkecuali dengan budaya baru yang dijalankan dengan harapan kesadaran untuk membiasakan hidup sehat. Materi dan diskusi yang disampaikan oleh pak heri ini berakhir tepat pada pukul 10.15 WIB. 


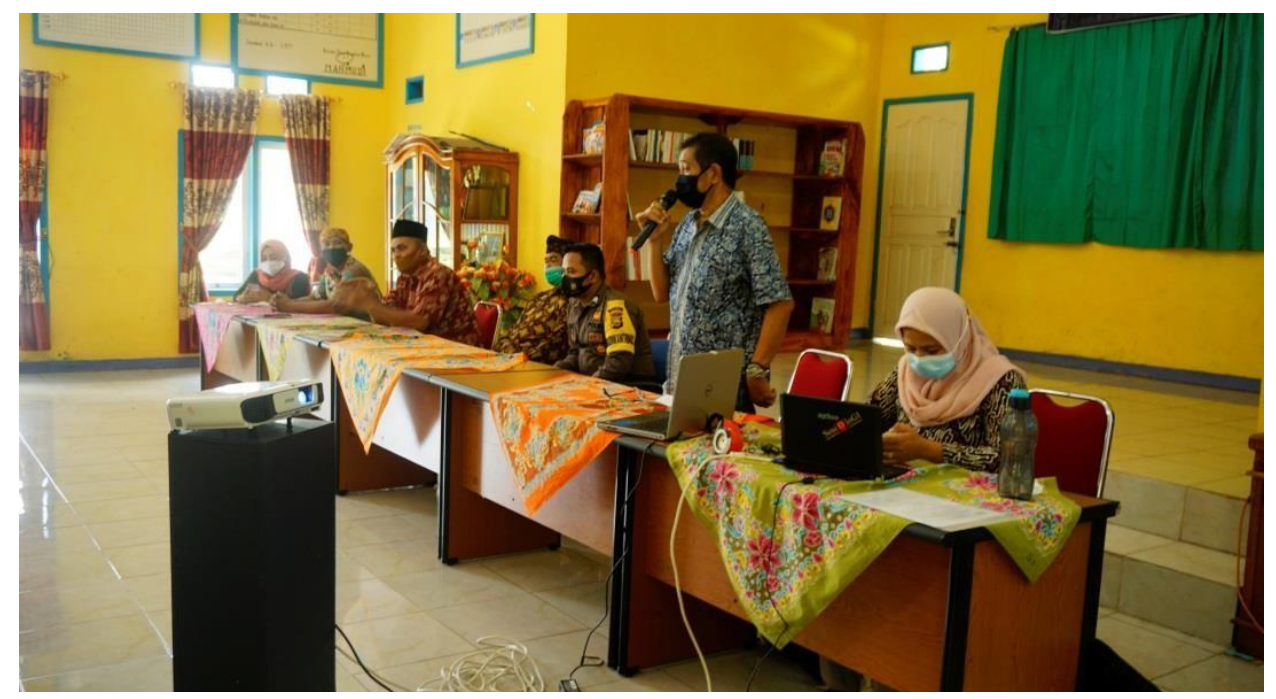

Gambar 08.

Penyampaian Materi Hari Ke II Oleh Drs. Heri Sunaryanto, Ph.D

Materi dalam sesi 2 disampaikan oleh Drs. Sumarto Widiono, M.Si dalam inti materi ini disampaikan tentang "menumbuhkan pengetahuan hidup sehat atas terjadinya perubahan sosial di era modern".

Pada intinya materi ini difokuskan untuk mendeskripsikan perihal situasi perubahan kebudayaan yang terjadi termasuk didalamnya ialah budaya berprilaku yang mendukung pola hidup sehat. Harapannnya mereka dapat memahami dan bisa membedakan bagaimana perubahan sosial yang terjadi pada era modern saat ini. Materi diskusi yang disampaikan oleh pak sumarto berakhir tepat pada pukul 11.15 WIB. 


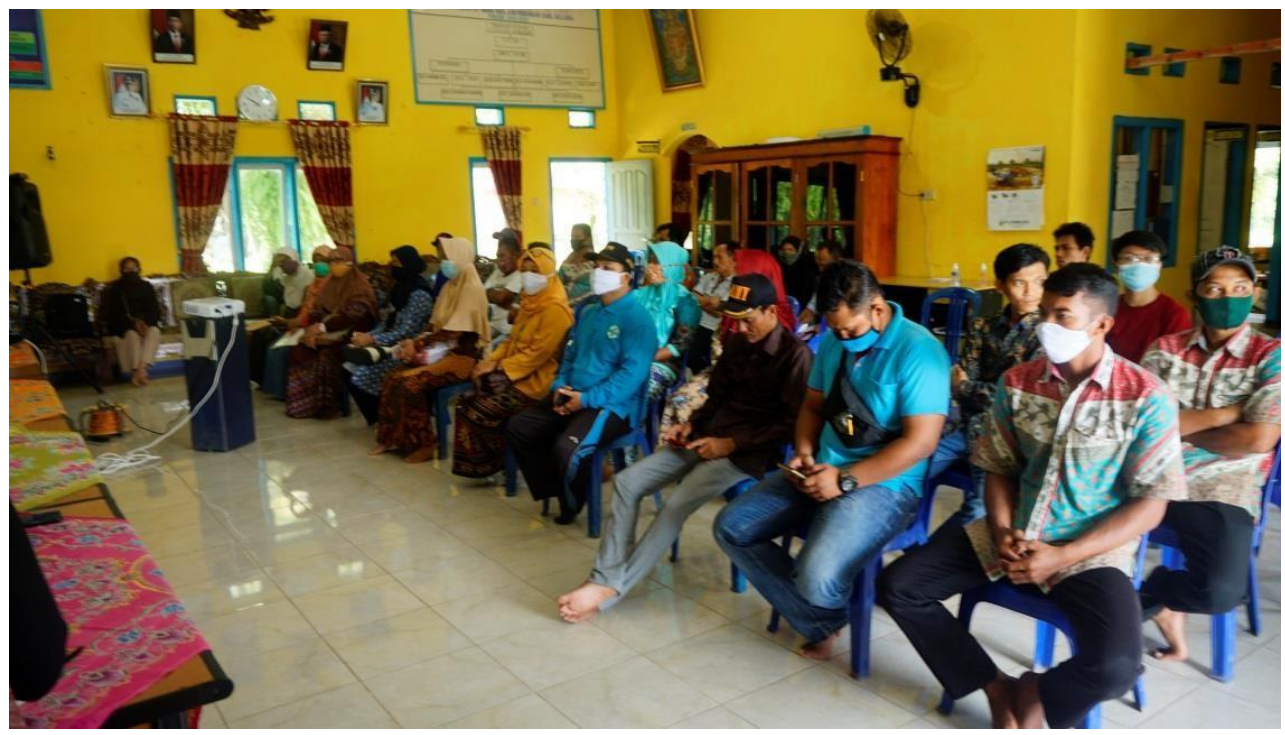


Gambar 09.

Peserta Dalam Kelompok II, Mendengarkan Informasi Bersama Narasumber Drs. Sumarto Widiono, M.Si

Penyampaian materi di sesi ke 3 ialah dari Diyas Widiyarti, M.A yaitu dengan pembahasan terkait praktik pembuatan masker sederhana. Harapannya bahwa masker yang setiap hari dibutuhkan dan digunakan dapat dibuat sendiri dengan pemanfaatan kain yang ada di rumah tangga yang masih dalam kondisi bersih dan layak digunakan sehingga tidak menjadi konsumtif membeli masker yang ada di pasar atau toko-toko. Materi sesi 3 berakhir tepat pada pukul 13.00 WIB

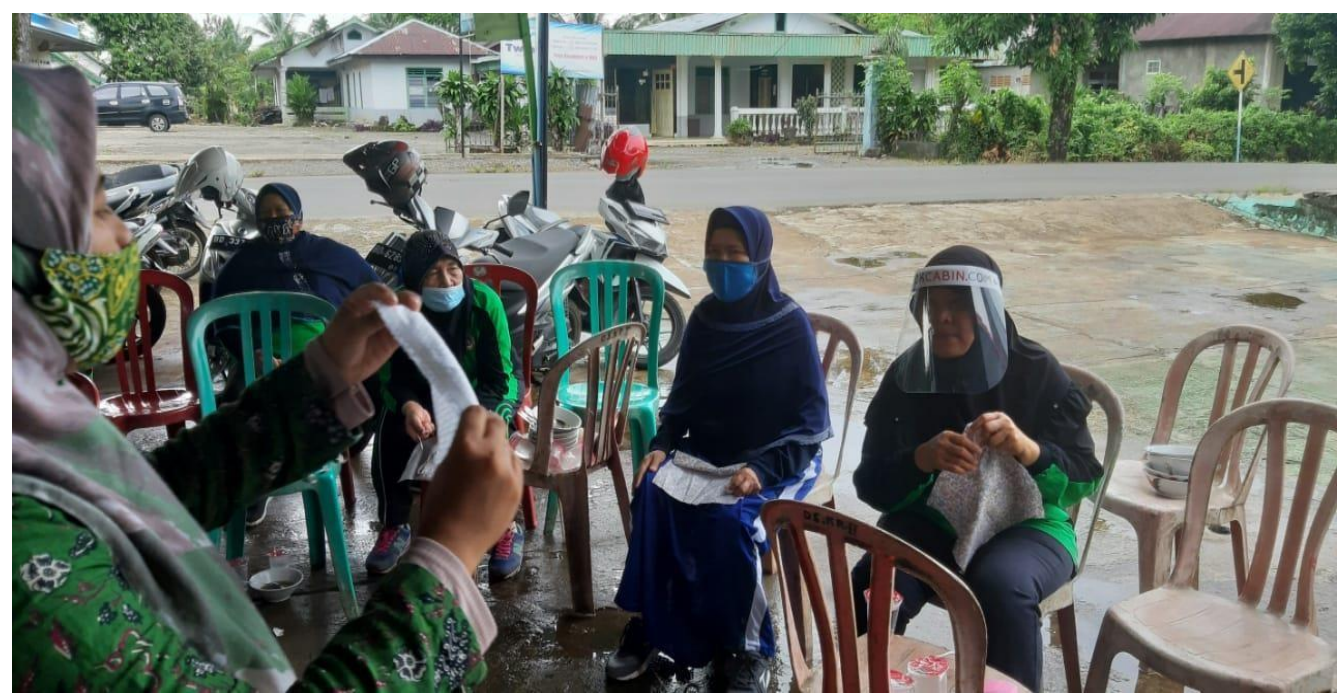

Gambar 10.

Peserta Kelompok II Membuat Masker Bersama Narasumber Diyas Widiyarti, M.A 


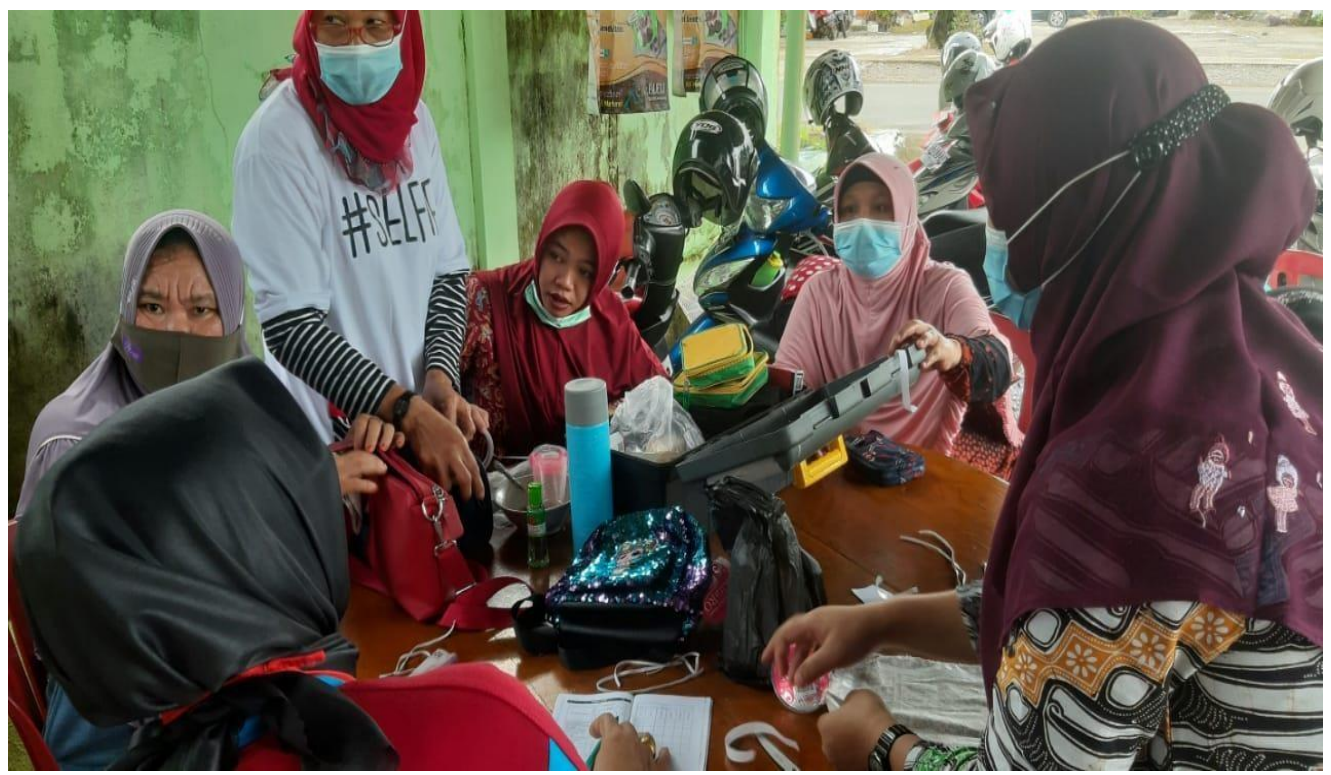

Gambar 11.

Peserta Langsung Membuat Masker Dengan Alat dan Bahan yang Telah Disediakan oleh Tim PPM.

\section{KESIMPULAN DAN SARAN}

Kesimpulan yang dapat kami sampaikan adalah sebagai berikut:

1. Kegiatan yang telah dilaksanakan adalah sosialisasi upaya peningkatan pengetahuan hidup sehat mencegah covid 19 bagi masyarakat dengan pokok informasi yaitu Strategi dan langkah yang dilakukan oleh masyarakat desa marga sakti menghadapi dan mencegah pandemi virus covid-19, menumbuhkan pengetahuan hidup sehat atas terjadinya perubahan sosial di era modern, pembuatan masker sederhana dan pemberian fasilitas pencuci tangan bagi perwakilan kelompok masyarakat desa marga sakti.

2. Peserta sangat partisipatif dan antusias dalam mengikuti rangkaian kegiatan yang telah dilaksanakan oleh tim pelaksanaan pengabdian

3. Peserta mampu memahami langkah-langkah yang harus disiapkan dalam menciptakan budaya hidup sehat mencegah covid19.

Berdasarkan kesimpulan diatas, tim pelaksana pengabdian dapat menyampaikan saran berikut:

1. Tim pengabdian diharapkan dapat intensif dalam memberikan informasi yang berkelanjutan mengenai permasalah covid19 bagi kelompok masyarakat desa khusnya di desa marga sakti. 
Politeknik Penerbangan Palembang

2. Tim pengabdian diharapkan memberikan pengetahuan terkait dengan alternatif membuat produk seperti: handsainitaizer yang berbahan alami dan membuat disinfektan yang dapat dimanfaatkan oleh keluarga. 


\section{DAFTAR PUSTAKA}

Call Center Dinas Kesehatan Kota Provinsi Bengkulu 2020

Endang Susanti dan Nur Kholisoh. 2018. Kontruksi Makna Prilaku Hidup Sehat. Jurnal Lugas

Ritzer George \& Goodman, Douglas J, 2007. Teori Sosiologi Modern. Edisi Ketujuh. Jakarta: Kencana.

Sumarto Widiono, Drs, Msi. 2019. Membudayakan Cuci Tangan Pada Usia Sekolah. Jurnal Sosiologi Nusantara.

Internet :

http://mangihot.blogspot.com/2016/11/budaya-hidup-sehat.html diakses, 05 maret 2020 pukul 13.00 Wib

https://www.alodokter.com/virus-corona diakses, 09 maret 2020 pukul 17.00

Anne. 2010. Gaya Hidup Sehat. 